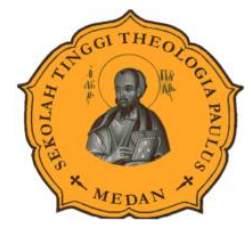

\title{
Pelayanan Kaum Muda dalam Menciptakan Generasi yang Bersinar
}

\author{
Herawati Barus \\ Sekolah Tinggi Theologia Paulus, Medan \\ h-barus@gmail.com
}

\begin{abstract}
This essay foccused on Youth and their power. Youth is a period of human being where they are full of pirit, power and also talanted. All of that kind are groove inside them. If all of aspects lead perfectly to the human calling as a witnessed of Almighty based on The God's Words (Gen.1:26-28), The youth will produce the good deeds for the benefide oh human being and also will lead to glorified The Creator of everything. Unfortunately, If the parents, the leader or the spiritual guider of them rule them into the wrong way, means there are many disasters are waiting for their generation, not only for human being but also for the continiously living in this universe will be in danger. The point of leading and coaching them in a good perseptive are needed in youth period in case to build the shining generation for the future,because the Young people are the agent of transformation.
\end{abstract}

Key Word: generation; shining generation; integral mission; youth

\begin{abstract}
Abstrak: Fokus utama dari tulisan ialah tentang pemuda dan kekuatannya. Pemuda adalah sebuah masa dalam kehidupan manusia, dimana semua semangat, kekuatan dan talentanyasedang berkobar-kobar. Bila semangat,kekuatan dan talenta ini di arahkan dengan tepat sesuai dengan kodrat kemanusiaan, yaitu menjadi berkat dan pengelola yang sesuai dengan Firman Tuhan (Kej.1:26-28), maka pemuda itu akan menghasikan gelombang-gelombang keberhasilan yang membawa kebahagian bagi manusia dan dunia ini dan sekaligus membawa kemuliaan bagi nama Tuhan. Namun sebaliknya bila orang tua dan pendidik atau pemimpin mereka; baik secara rohani dan intelektual gagal membimbing mereka berarti akan diprediksikan bahwa akan ada zaman kekacauan pada masa mereka kelak. Jadi pembinaan dan pelatihan pemuda dalam porsi yang benar sangat diperlukan untuk sebuah jaman dimana akan di temukan sebuah zaman yang generasinya akan bersinar, karena pemuda adalah agent perubah.
\end{abstract}

Kata Kunci: anak muda; generasi; generasi bersinar; misi integral

\section{PENDAHULUAN}

Peranan anak muda sangatlah penting dalam meneruskan kelangsungan hidup sebuah keluarga, gereja, bangsa bahkan dunia ini. Oleh karena itu, maka perlu sebuah perhatian khusus dalam menanganani mereka untuk mampu mempergunakan akal budi mereka secara tepat dan sesuai dengan firman Tuhan. Namun adanya pergeseran budaya dari zaman ke zaman sangatlah mempengaruhi kehidupan kaula muda saat ini. Hal-hal yang dianggap tabu pada masa lalu menjadi sangat biasa bagi mereka. Bahkan ada kecenderungan apabila mereka bisa melakukan sesuatu yang dianggap tabu atau bersifat larangan pada masa lampau, mereka akan disebut "anak gaul" (anak yang mengikuti trend masa kini). Mereka cenderung merasa tidak perlu untuk dinasehati. Melawan orang tua dan 
guru mereka, juga merasa mampu untuk menapaki hidup mereka. Mereka cenderung konsumeris dan hilangnya perasaan peduli kepada orang lain maupun lingkungan. Banyak sekali penyimpangan-penyimpangan kelakuan anak muda yang sangat meresahkan. Penyimpangan-penyimpangan itu biasanya melanggar hukum pidana dan cenderung merugikan diri mereka sendiri dan sosial dimana mereka tinggal. ${ }^{1}$ Pada umumnya hal-hal itu terjadi pada masa usia transisi mereka dan adanya kebutuhan akan pengakuan dari kelompok atau keluarganya bahwa mereka sudah dewasa.

Menurut Selvester M. Tacoy, M.Div, "Masa dewasa dini sebagai masa keterasingan sosial karena banyak anak muda yang sejak anak-anak dan remaja terbiasa bergantung kepada persahabatan dan kelompok mereka. Dan masa dewasa dini mereka mereka harus bekerja sendiri, berjuang sendiri, dan hal itu akan memisahkan mereka dengan kelompok mereka. Hal itu menimbulkan keterasingan yang didefinisikan adanya semangat bersaing dan hasrat kuat untuk maju dalam karier. Dengan demikian keramahtamahan pada masa remaja itu diganti dengan persaingan dalam masyarakat dewasa.",2

Tentu saja anak-anak muda gereja juga merupakan bagian dari anak-anak muda pada masa ini. Oleh sebab itu perlu sebuah usaha ekstra untuk memulihkan kembali keadaan mereka menjadi sebuah generasi yang bersinar dan takut akan Tuhan. Dietrich Bonhoeffer, seorang pendeta Lutheran berkebangsaan Jerman, mengatakan bahwa "Kekristenan tanpa pemuridan adalah kekristenan tanpa Kristus"3. Bila kita berbicara tentang pemuridan maka akan ada dua pihak yang harus muncul yaitu sebagai guru dan sebagai murid. Anak-anak. remaja dan kaum muda dalam gereja membutuhkan pemuridan itu. Sehingga seluruh lingkup kehidupan mereka merupakan cerminan mereka pada masa yang akan datang. Selanjutnya mereka meresponi Firman Allah yang hidup itu dan menjadi saksi Kristus dalam kehidupan mereka. Pelayanan kaum muda yang tepat dan benar akan menghasilkan sebuah generasi yang gemilang pada masa mereka nantinya. Tuhan Yesus melakukan pemuridan yang benar kepada dua belas muridnya untuk meneruskan misi-Nya. Misi Tuhan Yesus berhasil tersebar ke seluruh dunia dan banyak orang mengenal siapa Tuhan Yesus dan merasakan Kasih-Nya yang luar biasa itu melalui kesaksian hidup murid-murid-Nya.

Gereja-gereja saat ini juga harus memikirkan generasi penerusnya dan mempersiapkan para pemuda dalam pemuridan sehingga akan menjadi pemimpin-pemimpin yang berkarakter Kristus dan berpengaruh pada masanya. Tanpa pemuridan seperti yang dilakukan Yesus, kehidupan kekristenan akan menjadi self-centered atau kehidupan yang hanya berpusat pada diri sendiri.

\section{METODE}

Metode yang digunakan dalam artikel ini adalah analisis sosial dan deskriptif biblikal. Metode digunakan untuk menggambarkan situasi atau keadaan yang terjadi berkaitan dengan gereja sekarang ini, di mana tantangan kemerosotan moral di kalangan anak muda mendorong gereja untuk menciptakan generasi yang bersinar.

\footnotetext{
${ }^{1}$ http:/ kejahatan remaja.com. diakses pada Jum'at, 1 Juni 2012, pukul 21.56 Wib

${ }^{2}$ Selvester M. Tacoy, M.Div, Kunci Sukses Melayani Kaum Muda (Bandung : Yayasan Kalam Kudus, 2009), 59.

${ }^{3}$ Jurnal, Salvation, Edisi 14, Juli 2011, 2.
} 


\section{Generasi yang bersinar}

Hakim-Hakim 2:6-14, setelah Yosua membagi warisan kepada bangsa Israel maka Yosua membiarkan bangsa itu pergi untuk menempati warisan-warisan mereka. Bangsa Israel sangat taat dan memuja Allah Israel selama kepemimpinan Yosua. Adanya seorang pemimpin yang berkharisma dan takut akan Tuhan sangatlah menentukan cara hidup sebuah bangsa atau kelompok. Tetapi pada ayat 10-11 dijelaskan bahwa setelah Yosua dan angkatan yang percaya meninggal, maka bangkitlah sebuah angkatan yang tidak takut lagi kepada Tuhan. Mereka menyembah ilah-ilah yang lain yaitu para baal dan para asytoret.

Dari nats di atas, terlihat kegagalan angkatan yang tidak takut akan Tuhan dan cenderung tidak percaya dan melawan Allah yang sudah membebaskan mereka dari tanah pembuangan. Kurangnya perhatian terhadap pertumbuhan iman para generasi penerus mereka dan kurangnya pembelajaran tentang pengenalan tentang Allah kepada generasi penerus mereka menimbulkan ketidaksiapan dan kehilangan kompas iman para generasi penerus mereka. Karena kegagalan para tua-tua menanamkan rasa takut akan Tuhan pada generasi itu muncullah sebuah malapetaka dalam kehidupan mereka. Mereka dikutuk dan ditinggalkan oleh Allah dan tidak bisa menjadi berkat bagi orang lain.

Bercermin dari nats di atas maka tidak bisa dipungkiri hal itu terjadi juga pada masa sekarang ini. Adanya angkatan yang tidak mengenal dan tidak percaya kepada Tuhan. Banyaknya anak-anak muda gereja yang secara tidak sadar menyembah ilah-ilah lain. Terkontaminasi dengan kemajuan teknologi yang cenderung bersifat agnostic. Bila dahulu orang Israel menyembah para baal dan dewa asytoret maka sekarang tuhan/ilah mereka adalah diri mereka sendiri, Tuhan mereka adalah ilmu pengetahuan, olah raga atau materi. Di seluruh aspek kehidupan hal ini sungguh nyata bisa dilihat termasuk di lingkungan gereja sendiri, sering kali muncul hal-hal yang menyimpang karena tindakan-tindakan para pemuda tersebut. Tidak adanya filter yang benar yaitu firman Allah yang membuat mereka menjadi seperti kehilangan kompas moral mereka. Sering kali kelakuan-kelakuan mereka menjengkelkan para orang tua ataupun para guru dan para pengajar rohani mereka. Akibatnya sering penghakiman diberikan kepada mereka karena tindakan-tindakan mereka. Dicap sebagai pembangkang, perusak, pengacau dan juga tidak bertanggung jawab. Tidak bisa diandalkan dan sering membuat ulah.

John Piper mengatakan "walaupun berbicara tentang anak-anak, tetapi maksudnya juga sebenarnya berbicara kepada para orang tua dan kita semua yang sudah dewasa imannya." Selanjutnya dia juga mengatakan bahwa terkadang karena penghakiman kita dan juga pendekatan yang tidak tepat membuat mereka menjadi seorang yang memberontak. Selanjutnya cara berkomunikasi yang tepat sangat kurang antara orang tua dan kaum muda saat ini. Firman Tuhan mengatakan bahwa orang tua haruslah mengajari berulang-ulang tentang firman Allah yang sudah mereka kenal dan menjadi cara hidup mereka, kepada keturunan mereka baik di rumah,diperjalanan, apabila mau tidur ataupun saat terbangun (Ul 6:6-9). Tetapi hal itu sering menjadi hal yang terlupakan karena kesibukan.

\footnotetext{
${ }^{4}$ www.desiringgod.com diakses pada hari Rabu, 30 Mei 2019 pukul 10.00 Wib
} 
Oleh karena itu, dengan kata lain adanya kecenderungan pemenuhan spritualitas selalu menjadi anak tiri dalam kehidupan seorang anak. Yang menjadi prioritas adalah kebutuhan secara materi. Hal ini cenderung menyebabkan seorang anak tidak menjadi dewasa dalam hidup mereka. Kebutuhan spritualitas yang seharusnya menjadi dasar yang kokoh dalam membentuk karakter mereka sangatlah tipis sehingga mudah goyah apabila ada godaan. Seseorang tidak punya dasar yang kokoh yaitu iman kepada Allah maka mereka akan cenderung manjadi manusia yang labil dan menjadi korban dari zaman ini sendiri. Keputusasan bahkan ketidakpuasan terhadap anak-anak mereka terjadi di pihak orang tua dan para pengajar rohani. Di samping itu, adanya sosok yang tangguh dan tegas dalam beriman akan menjadi sosok yang menggetarkan hati para kaula muda. Seperti halnya Yosua yang sangat karismatik dan takut akan Tuhan mampu menyatukan bangsa Israel dalam penyambahan yang benar kepada Tuhan Allah Israel pada masanya.

Di sisi lain, keputusasaan para kaula muda untuk mengerti apa maksud dari orang tuanya juga sangat membuat mereka terkadang frustasi. Mereka merasa tertekan atas tuntutan yang diberikan kepada mereka. Hal ini tercermin dari sebuah kata sambutan yang di ucapkan kaula muda pada sebuah acara doa sedunia di Sentul, Jawa barat:

Ayah, ibu, dan semua orang yang mengasihi kami, Mungkin senjata kalian dalam masa kalian tidak cocok kami pakai pada masa kami. Seperti Daud yang tidak cocok dengan senjata yang Saul berikan untuk melawan Goliat, Daud hanya butuh sebuah batu kecil dan umpannya mampu membunuh Goliat si raksasa itu. Oleh sebab itu biarkanlah kami memakai senjata kami yang mungkin sangat kecil Untuk membunuh goliat-goliat pada masa kami. ${ }^{5}$

Dari hal-hal yang muncul di atas maka peran orang tua dan para guru spiritual sangatlah penting untuk membentuk karakter seorang anak. Ada ungkapan seorang anak muda yang mengakui bagaimana peranan yang sangat dia butuhkan dalam pencarian dirinya. Dan hal yang sangat penting itu adalah bagaimana para tua-tua yang dia hormati mampu memberi mereka semangat dan juga fasilitas yang tepat dalam menjalani hidup mereka dan mereka dia akui bahwa tanpa orang-orang tua yang mangasihi mereka dan tanpa dukungan mereka, mereka tidak ada apa-apanya. Pencarian dirinya akan sosok yang bisa memuaskan hidupnya yaitu Tuhan Yesus.

\section{PEMBAHASAN}

Sebagai orang yang sudah dewasa imannya maka wajiblah pemimpin gereja membenahi para penerus generasi gereja. Evaluasi yang tepat dan cara yang benar akan sangat menolong kita untuk menolong mereka supaya bisa bangkit kembali. Adanya pemenuhan kebutuhan secara holistik bagi kaum muda akan sangat menolong mereka untuk bisa melihat apa sebenarnya misi kehidupan yang Tuhan sudah berikan bagi mereka masingmasing. John Piper mengatakan "bahwa Tuhan sendiri sudah berbicara kepada anak-anak itu." Oleh sebab itu, dalam pelayanan terhadap para kaum muda ini, khususnya kaum muda gereja, kita harus sanggup merendahkan diri dan berempati untuk merasakan pergumulan mereka sendiri dalam pencarian jati diri mereka menjadi pengemban-pengemban misi dari

\footnotetext{
${ }^{5}$ www.worldprayerassembly.com 18 mei 2019, 11.30
} 
Allah sendiri. Kita tidak bisa menghakimi mereka sebelum mengerti masalah sebenarnya dan kalaupun perlu dikritik pakailah cara yang tepat sehingga mereka tidak akan menghindar dari kita.

Pelayanan kaum muda adalah sebuah solusi yang bisa menjangkau mereka dan mengubah pola pikir mereka. Secara kasat mata kita melihat kaum muda gereja kita sungguh sangat beriman tetapi sesungguhnya mereka adalah orang-orang yang rapuh dan ingin mencari sosok yang menjadi figur mereka dalam kehidupannya. Pengalaman penulis selama studi di sebuah sekolah tinggi teologia menjadi sebuah pelajaran penting. Kaum muda yang masih baru masuk sering menjadi orang yang kehilangan jati diri. Akibatnya, mereka cenderung menjadi pemberontak kepada kakak-kakak senior mereka. Mereka merasa ditekan diabaikan dan juga diintimidasi. Bahkan setelah penulis mengadakan pendekatan dengan mereka maka penulis menemukan sebuah pandangan baru dari mereka yang dikatakan oleh kaum muda itu: "kami butuh tindakan bukan perkataan, dan kami seringkali menemukan bahwa kakak-kakak kami adalah orang bermuka dua dan itu sangat membuat kami terguncang dan frustasi, kami bosan melihatnya."

Hal ini sungguh meruntuhkan pendapat penulis selama ini karena penulis juga cenderung menghakimi anak-anak didiknya karena "kenakalan mereka". Oleh sebab itu penulis berusaha mengaplikasikan konsep Misi Integral kepada sekelompok anak muda yang ada di sekolah tinggi tersebut. Hasilnya sungguh luar biasa dimana sekarang ini sudah ada pelayanan kontekstual yang dilakukan oleh kelompok ini, dengan melayani anak-anak non Kristen di sekitar mereka dalam belajar bahasa Inggris.

Adapun pelayanan terhadap kaum muda itu haruslah bisa menyetuh ke dalam hati mereka sehingga mereka bisa menyadari bagaimana berharganya mereka di hadapan Tuhan dan bagaimana Tuhan berharap besar terhadap mereka untuk menunaikan misi-Nya untuk menyatakan kasih-Nya. Kemampuan untuk membuka wawasan mereka tentang potensi intelektual mereka dalam melayani sesama. Kedua faktor tersebut yaitu keseimbangan antara kedewasaan spiritual dan kematangan dalam intlektual akan membuat mereka semakin signifikan dalam melayani.

Dari konsep di atas, ada beberapa faktor yang harus dilakukan untuk pemulihan hati mereka tentang konsep hidup dan menjadi jati diri mereka dan hubungan mereka dengan Tuhan. Menurut William P. Philips "untuk membentuk pribadi seseorang baik itu kesalehannya, kehormatannya,dan integritasnya seharusnya tidaklah bercela. Dia harus menjadi contoh yang benar bukan hanya dalam lingkupan masyarakatnya saja tetapi dalam seluruh aspek kehidupannya dimanapun dia berada. Selanjutnya kebiasaan-kebiasaan dan tingkah lakunya seharusnya tidak ada celanya. Untuk membentuk karakter ini maka seseorang itu akan dibangun melalui doa, pembelajaran alkitab dan pelayanan." ${ }^{\circ}$ Oleh sebab itu kita harus membentuk mereka menjadi sosok yang kuat dan tangguh dalam sikap dan juga berkarakter Kristus.

\footnotetext{
${ }^{6}$ William P.Philips, The Adult Departemant of the Sunday School (Nashville, Tennessee,1935), 31
} 
Adapun usaha-usaha yang bisa dilakukan untuk pemulihan Hubungan mereka dengan Tuhan dan menimbulkan percaya diri adalah:

Pertama, pendekatan secara pribadi (pastoral konseling) sangatlah penting bagi setiap anak karena pada umumnya mereka punya masalah-masalah yang kadangkala mereka tidak bisa ucapkan dan tidak terlampiaskan. Bila itu tidak ditangani dengan serius, itu bisa sangat merugikan bagi kehidupannya maupun kehidupan sosial sekitarnya. Dalam hal ini kakak-kakak yang berperan sebagai pembibing harus selalu waspada dan memantau pertumbuhan rohani bagi andik-adik rohaninya. Contohnya: studi kasus atas sekelompok mahasiswa baru di sebuah Sekolah Tinggi Teologia. Mereka frustasi karena tidak ada pendekatan yang benar akan mereka. Yang mereka hadapi setiap hari adalah tuntutantuntutan dan keharusan-kaharusan dan mereka sendiri melihat orang yang menuntut dan mengharuskan mereka juga tidak pernah melakukan hal itu. Akibatnya mereka memberontak dan cederung apatis terhadap kakak-kakak mereka. Tetapi, ketika ada pemberesan diri dan keterbukaan dengan cara konseling maka mereka bisa pulih dan bahkan lebih maju dalam berpikir untuk pelayanan dari kakak-kakak seniornya.

Kedua, bimbinglah mereka dalam firman Tuhan dan ajaklah selalu berdoa dan tanamkan gaya hidup berdoa bagi mereka sehingga mereka akan menjadi pribadi yang tenang dan kuat dalam prinsip hidup.

Ketiga, tuntunlah mereka menjadi pelaku firman Tuhan, bukan hanya mendengar saja dan hidup diawan-awan tetapi ajaklah mereka memulai dari tingkat terkecil sebagai saksi bagi Kristus sehingga dengan demikina Firman itu membumi bisa menyentuh setiap orang. Cara lain mengajak mereka melakukan bakti sosial atau hal-hal yang bisa menimbulkan belas kasihan di hati mereka ketika membawa mereka mengunjungi orang sakit, menolong korban bencana alam, mengajar anak yatim piatu dan kegiatan sosial yang lainnya. Satu contoh yang sangat menggugah saya ketika kami membawa anak-anak non-Kristen di sekitar kampus yang kami ajari bahasa Inggris, berenang gratis karena ada sponsor yang kami dapat, anak-anak kecil itu berenang dengan riang dan sangat gembira. Satu orang dari tim pengajar (kelompok yang saya bimbing selama studi di sekolah teoligia itu) menangis dan berkata: " kakak hatiku sangat sukacita mendengar anak-anak itu tertawa bahagia dan aku mau melakukan lebih bagi mereka”. Saya hanya tersenyum tetapi hati saya mengatakan terima kasih Tuhan ini awal misiMu akan berjalan dalam hidupnya.

Keempat, berusahalah mendekatkan mereka dengan lingkungan mereka dengan menanamkan dan memperaktikan buah roh (Gal. 6:22-23) saling peduli dan saling mengasihi tanpa memandang ras, suku, bangsa, bahasa dan juga agama. Tanamkan rasa mengasihi bagi sesama dan hidup sopan santun adalah gaya hidup anak Tuhan.

Kelima, tanamkan hidup untuk bermisi seperti yang dipesankan Tuhan Yesus untuk menjadikan segala bangsa menjadi murid-Nya (Mat. 16:15,Yoh 20:21). Patahkan perasaan mereka yang sering mengatakan bahwa mereka tidak mampu karena terlalu berat. Tanamkan selalu percaya diri dan percaya Kepada Tuhan sang pemilik misi itu sendiri.

Keenam, buatlah jaringan yang kuat di dalam pelayanan terhadap pemuda, misalnya, bila suatu saat mereka harus pergi bekerja ke suatu tempat; buatlah pos-pos dimana mereka akan selalu berjumpa di tempat itu untuk sharing maupun membuat pelayanan yang akan semakin melebar. Seperti beberapa bulan yang lalu kami mengadakam pelayanan di 
Hongkong yang ditangani oleh seorang orang warga negara Hongkong, tapi yang dilayaninya ialah orang Indonesia (TKI) yang bermasalah. Setelah TKI itu minta tolong kepadanya maka ia selalu menyediakan lapangan pekerjaan yang baru dan menjamin bahwa dia tidak akan kena masalah lagi. Dia tidak pernah memaksa para TKI itu untuk masuk Kristen tapi karena begitu kasihnya ibu itu kepada setiap orang TKI yang ada bersama-sama dengan dia, maka hampir semua masuk Kristen dan mereka merasa punya kehidupan yang berbeda sehingga kemanapun mereka pergi mereka selalu membawa Injil bersama mereka. Untuk tetap menjangkau mereka dan memantau apa yang mereka kerjakan apa yang mereka alami maka ibu itu membuat pos-pos di mana anak-anak rohaninya berada, sehingga mudah menagani masalah mereka dimanapun mereka berada. Setiap pos itu sudah ada yang bertanggung jawab atas setiap anggotanya bila mereka tidak bisa ditangani maka mereka lapor ke ibu rohani mereka.

Ketujuh, persiapkan mereka sebagai penerus generasi dan menjadi pemimpin yang takut akan Tuhan pada generasi mereka dengan pengenalan yang benar akan Allah dan juga pengisian akan intelektual yang seimbang.

Dalam hal penyeimbangan pelayanan mereka maka kosep Misi Integral ${ }^{7}$ sangatlah cocok diterapkan dalam pelayanan kaum muda. Sebagai mahasiswa teologia sering kali dijumpai sebuah konsep yang kurang tepat dalam pemaham tentang misi. Dalam hal ini mahasiswa teologia sering megalami kebimbangan bahkan sikap yang apatis terhadap misi. Akibatnya dalam pelayanan mereka misi itu tidak berjalan. Sebagai seorang pengemban sebuah tugas pelayanan kepada Tuhan seseorang itu harus mengenal pelayanan itu secara holistik dan sesuai dengan konsep Firman Tuhan yang memberi mandat bagi umat pilihannya untuk menjaga dan memelihara seluruh ciptaanNya. Seringkali terjadi pengkotak-kotakan tentang misi dan teologia dalam pemahaman mereka.

Perlu dilakukan Misi Integral dengan menerapkan langsung pemahaman mereka untuk menjadi saksi-saksi Kristus dengan mengajar anak-anak yang belum mengenal Tuhan, memberikan mereka pendidikan. Adapun langkah-langkah yang dilakukan ialah:

Pertama, mengajari anak-anak muda (dalam hal ini mahasiswa STT sejumlah 10 orang) untuk melihat apa yang akan dilakukan untuk menerapkan Misi Integral di sekitar kampus. Bukan sebuah kebetulan jika dalam kesempatan ada seorang ibu yag meminta agar anak-anak membantunya dalam mengajar anak-anak sekitaar rumahnya. Kedua, dalam pelaksaan Misi Integral ini, anak-anak muda diberi tugas sesuai dengan talenta mereka. Dari sepuluh orang tersebut ada tiga orang yang punya potensi berbahasa Inggris yang cukup baik, ada juga yang bisa matematika dan ada juga yang pintar bermain musik dan yang belum memiliki kemampuan yang menonjol maka dia diberi tugas dalam hal administrasi. Tim dibagi dalam tiga kelompok yang semua talenta itu ada didalamnya.

Ketiga, dalam pelayanan, semua anggota benar-benar bersatu baik secara hati, talenta dan juga konsep untuk boleh menjadi berkat. Buat pendekatan untuk melayani dan mengajarkan anak-anak di beberapa tempat mengenai pelajaran yang mereka senangi. Dengan adanya pendekatan terhadap anak-anak maka hubungan dengan masyarakat semakin baik.

\footnotetext{
${ }^{7}$ www.integral-mission.com, diakses pada hari Sabtu, 26 Mei 2019, pukul 20.18 WIB
} 
Hal di atas adalah sebuah program Misi Integral yang menghasilkan sebuah misi yang baru. Pada awalnya misi ini khusus untuk pelayanan kaum muda yang sedang mencari jati diri mereka. Ketika ada pemulihan bagi diri mereka sendiri dan sebuah konsep pengenalan terhadap penggilan mereka, maka mereka menjadi berkat untuk orang-orang yang ada di sekitarnya. Dengan power yang berupa talenta baik secara intelektual dan talenta-talenta lainnya mereka bisa menjadi pelopor untuk kegerakan pencurahan Kasih Kristus di lingkungan dimana mereka tinggal. Diawali dengan sebuah langkah kecil dan menaburkan kasih bagi banyak orang. Bahkan untuk jangka panjangnya akan menjadi sebuah lompatan yang besar dalam pelayanan mereka. Mereka tidak hanya diajarkan untuk memimpin sebuah jemaat dengan bersembunyi di balik mimbar, tetapi meraka akan menjadi peka dengan kebutuhan lingkungan dimana mereka tinggal.

Gereja harus mampu menggerakkan kekuatan kaula muda untuk menjadi generasi yang tangguh pada masanya. Kemampuan untuk mengerti dan berempati kepada mereka dalam pergumulan sangatlah menunjang mereka menjadi sosok yang tangguh dalam perjalanan kehidupan yang sedang dicarinya. Adanya konsep bahwa mereka mampu melakukan apapun di masa muda sangatlah benar, Tetapi bagaimana seorang muda yang kuat dan tangguh itu bisa dipoles dengan cara padang yang benar yaitu dengan Firman Tuhan sehingga kekuatannya tidak akan terbuang sia-sia. Anak-anak muda layaknya seperti anak panah di tangan pahlawan. Bagian yang runcing adalah anak muda yang akan diluncurkan, bagian tengahnya yang menatang kekuatan itu adalah para orang tua dan para guru rohani mereka sedangkan bagian ujungnya adalah kaum yang lebih berpengalaman lagi yaitu orang-orang yang jauh lebih tua lagi dan merekalah yang menyeimbangkan anak panah tersebut agar meluncur tepat pada sasarannya.

Pelayanan kaum muda merupakan hal yang sangat penting bagi kelangsungan iman di muka bumi ini. Mereka merupakan generasi generasi yang akan mengubah sejarah setiap generasi. Apa yang menjadi pola pikir mereka akan menjadi sebuah hasil dan warna pada era mereka. Dari hal itu, maka kita sebagai orang-orang yang dewasa baik secara iman maupun secara umur, harus melihat mereka-sebagai pengganti untuk meneruskan kehidupan mereka. Apa yang kita tanam saat ini akan menjadi buah mereka pada zamannya. Oleh sebab itu, kita harus menmberikan sebuah pandangan yang menyeluruh secara benar kepada mereka. Dan tentulah itu harus berdasarkan kebenaran Firman Allah. Kita tidak bisa berbuat banyak pada masa yang akan datang tetapi kita bisa mewujudkan mimpi-mimpi kita bagi masa depan dunia untuk kemuliaan Tuhan, dengan menuliskannya mimpi-mimpi itu di loh hati para kaum muda gereja sebagai penerus generasi kita dan membentuk mereka menjadi saksi Kristus. Tetapi itu bukanlah hal yang mudah.

Pemahaman yang benar tentang siapa diri mereka juga adalah sebuah tantangan besar bagi mereka. Dalam hal ini mereka membutuhkan sosok yang mampu mengendalikan nafsu mereka yang cenderung masih liar. Tetap tenang dan tidak terpancing dengan kelakuan mereka juga dalah sebuah konsep yang harus kita miliki sebagai pemandu mereka. Terkadang orang-orang muda akan memberontak ketika dia dihakimi atau dituntut. Oleh sebab itu, sering terjadi sebuah keretakan hubungan dengan para tua-tua mereka. 
Hampir semua kawula muda mengalami hal tersebut. Adanya frustasi yang mendalam kepada orang tua, guru rohani mereka, kadang membuat mereka menjadi orang yang sulit untuk didekati. Oleh sebab itu, pembebasan dari rasa ketertekanan akan membuat mereka menjadi orang yang apatis. Pendekatan yang benar dan juga komunikasi yang baik akan membuat mereka menjadi pendengar yang baik dan akan menjadi orang yang baik dan penuh perhatian juga.

\section{KESIMPULAN}

Mempersiapkan kaum muda yang melayani dimulai dengan pendekatan untuk mengenali diri mereka secara utuh. Selama pelayanan dengan sekelompok anak-anak muda yang studi di sebuah sekolah teologi, hal mengenai pemulihan hati mereka dan juga pengenalan diri mereka terhadap Tuhan membuat mereka berbeda dengan sebelumnya. Diberkati untuk memberkati adalah sebuah konsep yang perlu ditanamkan bagi mereka untuk mampu menjadi saksi dimanapun mereka berada. Pelayanan kaula muda merupakan sebuah misi yang holistik karena di dalam mereka tersembunyi sebuah embrio kehidupan yang baru di masa yang mendatang. Misi integral akan sangat cocok diterapkan bagi mereka. Ketika mereka mengerti secara benar apa itu misi integral, maka mereka akan mengatakan bahwa bermisi itu tidaklah sulit. Dengan kemampuan mereka, mereka mulai bergerak dari satu level ke level berikutnya. Ada kegerakan yang akan terjadi ketika kaula muda sudah mengerti panggilan hidup mereka didalam mewujutkan kerajaan Allah di muka bumi ini. Hal itu akan terjadi ketika kasih mulai mereka tertanamkan dalam hidup mereka, kepedulian akan menjadi gaya hidup mereka dan peka akan kebutuhan masyarakat dimana mereka tinggal akan menjadi milik mereka. Sehingga generasi penerus yang bersinar yaitu sinar kemualian Allah akan mereka pancarkan di manapun mereka berada.

\section{REFERENSI}

Bruce, Powers.P. Christian Education Handbook. Broadman Press,USA,1981

Mark, Senter. Inovasi \& Visi Profetik dalam Pelayanan Kaum Muda. Yayasan Kalam

Hidup, Bandung.1992

Selvester, Tacoy M. Kunci Sukses Melayani Kaum Muda. Yayasan Kalam Kalam Hidup, Bandung.

William, Phillips P. The Adult Department of the Sunday school. Copyright in Nashville, Tennessee, 1935.

Jurnal Salvation, Jurnal. Edisi 14 Juli 2011.

http://www.kenakalanremaja.com

www.integral-mission.com

www.desiringgod.com.

www.wordprayerassembly.com 